\title{
Senam aerobik dan konsumsi zat gizi serta pengaruhnya terhadap kadar kolesterol total darah wanita \\ Siti Fatimah' ${ }^{1}$ Apoina Kartini²
}

\begin{abstract}
Background: Hypercholesterolemia is a condition in which levels of cholesterol in the blood above normal levels ( $\geq 240$ $\mathrm{mg} / \mathrm{dl})$. Physical exercises done regularly useful in the regulation of cholesterol, is a total cholesterol, LDL cholesterol and triglycerides in the blood decreased, while HDL cholesterol increased. Food an important role in association with the incident hipercholesterolemia.

Objective: The purpose of this study was to determine the effect of aerobic exercise on blood total cholesterol level of adult women in the city of Semarang.

Method: This research was explanatory research with cross sectional study. Sample were women aged 20-49 years gymnastic participants, as a comparison group was a housewife who was not doing gymnastics. Twenty three samples for group 2 by matching on nutritional status and age and with the sampling purposive sampling. Adequacy levels of carbohydrates, proteins, fats, and also vitamins $A$ and $C$ was obtained through $2 \times 24$-hour recall was not a sequence, and processed using nutrisurvey. Results of independent $t$-test used to determine the effect of cholesterol levels between groups, and chi square test was used to determine association with nutrient adequacy levels of total cholesterol.

Results: The results showed no significant difference in mean total cholesterol level between groups of gymnastic participants $(201.2 \mathrm{~g} / \mathrm{dl})$ with housewife group $(208.3 \mathrm{~g} / \mathrm{dl})$. Housewife group belonging to hypercholesterolemia by $52.2 \%$, while in group of exercise participants at $43.5 \%$. Sufficiency level of protein showed a role in the total cholesterol level of adult women.

Conclusion: The aerobic gymnastics did not affect total cholesterol. Moderate level of protein adequacy contributes to the total cholesterol level of adult women.
\end{abstract}

KEY WORDS aerobic exercise, total cholesterol, nutrition adequate level, adult women

\section{PENDAHULUAN}

Kemajuan teknologi dan industri secara tidak langsung telah meningkatkan penghasilan masyarakat. Dampaknya adalah daya beli masyarakat meningkat khususnya konsumsi bahan pangan. Pola makan masyarakat pada akhirnya akan bergeser dari pola makan tradisional ke arah pola makanan yang cenderung tinggi kadar kolesterol, protein, dan garam tetapi kurang serat. Hal inilah yang menyebabkan tingginya prevalensi penyakit degeneratif akhir-akhir ini, salah satunya adalah hiperkolesterolemia (1).

Hiperkolesterolemia adalah keadaan di mana kadar kolesterol darah meningkat melebihi kadar normal ( $\geq 240$ $\mathrm{mg} / \mathrm{dl}$ ) sebagai manifestasi kelainan metabolisme ataupun kelainan transportasi kolesterol. Hiperkolesterolemia merupakan salah satu bagian dari hiperlipidemia (peningkatan kadar kolesterol dan trigliserida darah). Ada dua jenis hiperkolesterolemia ditinjau dari sebabnya, yaitu hiperkolesterolemia primer dan hiperkolesterolemia sekunder. Hiperkolesterolemia primer selain bersifat herediter dapat dipengaruhi usia, jenis kelamin, stress, minum kopi berlebihan, makanan kurang serat, kurang aktivitas fisik, banyak merokok, dan alkoholik. Sebaliknya hiperkolesterolemia sekunder disebabkan oleh penyakit seperti diabetes mellitus, obesitas, sindroma nefrotik, hipertiroidisme, dan lain-lain $(1,2)$.

Kebiasaan melakukan olahraga merupakan faktor penting jika dibandingkan dengan jumlah dan jenis lemak pada diit untuk mengontrol kadar kolesterol darah. Keluarga yang mengonsumsi makanan sumber lemak tetapi mempunyai kebiasaan olahraga teratur, ternyata mempunyai kadar kolesterol darah relatif sama dengan keluarga yang mengonsumsi makanan rendah lemak dengan aktivitas fisik sedikit (tidak memiliki kebiasaan olahraga). Latihan jasmani yang dilakukan secara teratur sesuai kondisi tubuh bermanfaat dalam regulasi kolesterol yaitu menurunkan kadar kolesterol total, low density lipoprotein (LDL)-kolesterol, dan trigliserida, sedangkan high density lipoprotein (HDL)kolesterol meningkat secara bermakna. Latihan jasmani dapat menghilangkan lipatan-lipatan lemak seseorang dan membakar banyak kalori sehingga tubuh tampak lebih langsing dan berat badan menjadi ideal $(3,4)$.

Makanan memegang peranan penting dalam terjadinya hiperkolesterolemia. Komposisi kandungan zat gizi dalam makanan dapat berpengaruh terhadap tingginya kadar lemak darah. Lemak makanan merupakan komponen makanan yang berpengaruh sangat besar terhadap pengaturan metabolisme kolesterol. Zat gizi lain yang berpengaruh terhadap kadar lemak adalah

\footnotetext{
1 Fakultas Kesehatan Masyarakat Universitas Diponegoro, Kampus Tembalang Semarang JI. Prof. Sudarto SH Tembalang, Semarang 50239, Telp (024) 7460044, e-mail: fatimahpradig@yahoo.com

${ }^{2}$ Fakultas Kesehatan Masyarakat Universitas Diponegoro, Kampus Tembalang Semarang JI. Prof. Sudarto SH Tembalang, Semarang 50239, Telp (024) 7460044
} 
karbohidrat, protein, lemak, vitamin A dan C, serta mineral tertentu seperti kalsium. Makanan dengan kandungan karbohidrat primer yang tinggi berhubungan dengan hiperkolesterolemia, sedangkan karbohidrat kompleks tidak. Beberapa penelitian menunjukkan protein dari bahan pangan hewani berpotensi menyebabkan hiperkolesterolemia, sedangkan protein dari bahan nabati dapat mencegah terjadinya hiperkolesterolemia. Lemak jenuh cenderung meningkatkan kadar kolesterol, sedangkan lemak tidak jenuh dapat menurunkan kadar kolesterol dan trigliserida darah (5).

Penelitian yang dilakukan di Philadelphia tahun 1984 dalam suatu percobaannya menemukan dalam pemberian vitamin A terdapat pengurangan kadar kolesterol darah pada pasien penderita aterosklerosis. Peran vitamin A adalah mencegah teroksidasinya lemak tidak jenuh ganda, dengan demikian lemak tidak jenuh ganda dapat dipertahankan. Jika tubuh kita kekurangan vitamin $\mathrm{C}$ dapat terjadi kenaikan kadar kolesterol dalam hati. Diperkirakan fungsi vitamin C adalah mengubah kolesterol menjadi bahan lainnya. Vitamin C memecah kolesterol menjadi asam empedu dan garam empedu di dalam hati, kemudian akan diekskresikan dari tubuh sebagai feses. Selain zat gizi tersebut, serat tidak kalah penting perannya terhadap kejadian hiperlipidemia. Bahan pangan yang mengandung serat larut seperti beras, jagung, gandum, apel, dan sayuran hijau dapat mengurangi kolesterol dalam darah. Serat tidak larut mengandung sitosterol dan niasin yang berfungsi sebagai faktor hipokolesterolemik (5). Tujuan penelitian ini adalah untuk mengetahui pengaruh senam aerobik dan konsumsi zat gizi terhadap kadar kolesterol total darah wanita dewasa di Kota Semarang.

\section{BAHAN DAN METODE}

Jenis penelitian ini adalah explanatory research dengan cross sectional study. Subjek penelitian adalah peserta senam aerobik di sanggar senam ST. Anna yang aktif melakukan senam aerobik 3 kali per minggu selama 6 bulan. Subjek penelitian tidak merokok, bukan alkoholik, tidak minum kopi, dan bukan peserta KB pil. Sebagai pembanding adalah wanita dewasa bukan peserta senam aerobik, yang mempunyai karakteristik yang hampir sama dengan sampel penelitian dengan melakukan matching pada status gizi dan usia. Perbandingan jumlah sampel dan pembanding adalah 1 : 1 dengan cara pengambilan sampel secara purposive sampling. Penentuan besar sampel diestimasikan berdasarkan rumus pendugaan perbedaan antara dua proporsi dengan tingkat kemaknaan $(Z \alpha)$ sebesar $95 \%$ $(1,96)$; kekuatan uji $(Z \beta)$ sebesar $90 \%(1,28)$; simpang baku kadar kolesterol penelitian sebelumnya (sd) sebesar 5,5; dan perbedaan kolesterol total darah yang diharapkan antara sampel dan pembanding (d) sebesar 15. Berdasarkan rumus yang digunakan jumlah sampel minimal yang dibutuhkan sebanyak 21 orang untuk masing-masing kelompok (6).
Data karakteristik subjek (usia, merokok, konsumsi alkohol, dan kopi) diperoleh dengan menggunakan kuesioner terstruktur dan kuesioner penyaring. Data kadar kolesterol total diperoleh melalui pemeriksaan darah oleh Laboratorium Klinik Imam Bonjol dengan metode Accutrend. Data tingkat kecukupan zat gizi (karbohidrat, protein, lemak, serat, vitamin $\mathrm{A}$, dan $\mathrm{C}$ ) diperoleh berdasarkan metode recall $2 \mathrm{x}$ 24 jam secara tidak berurutan dengan bantuan food model serta diolah dengan nutrisurvey kemudian dibandingkan dengan angka kecukupan gizi (AKG). Pengambilan data dilakukan oleh enumerator yaitu mahasiswi Fakultas Kesehatan Masyarakat semester 8 sejumlah 3 orang. Variabel kolesterol total berdistribusi normal sehingga untuk mengetahui pengaruh senam aerobik terhadap kadar kolesterol digunakan uji t-test indepent. Variabel tingkat kecukupan zat gizi berdistribusi tidak normal sehingga untuk mengetahui apakah ada pengaruhnya terhadap kadar kolesterol digunakan uji Mann-Whitney $(6,7)$.

\section{HASIL DAN BAHASAN}

\section{Karaktersitik subjek penelitian}

Karakteristik subjek pada penelitian ini meliputi umur, berat badan (BB), dan indeks massa tubuh (IMT). Rerata umur kelompok ibu rumah tangga (IRT) yaitu 38,43 tahun, lebih tinggi dibanding rerata umur kelompok ibu peserta senam aerobik yaitu 31,96 tahun. Rerata berat badan kelompok IRT sebesar $58,78 \mathrm{~kg}$, sedangkan kelompok ibu peserta senam aerobik lebih rendah yaitu sebesar 55,71 kg. Rerata IMT kelompok IRT sebesar 25,84 sedangkan kelompok peserta senam aerobik lebih rendah yaitu sebesar 23,34 (Tabel 1).

Tabel 1. Karakteristik subjek

\begin{tabular}{lcccr}
\hline Karakteristik & Minimal & Maksimal & Rerata & SD \\
\hline Umur (tahun) & & & & \\
$\quad$ IRT & 25,0 & 49,0 & 38,43 & 7,757 \\
$\quad$ Peserta senam & 20,0 & 48,0 & 31,96 & 7,988 \\
BB (kg) & & & & \\
$\quad$ IRT & 39,3 & 82,6 & 58,78 & 11,1674 \\
$\quad$ Peserta senam & 40,0 & 80,4 & 55,71 & 9,9012 \\
IMT & & & & \\
$\quad$ IRT & 17,5 & 33,9 & 25,84 & 4,6798 \\
$\quad$ Peserta senam & 17,0 & 35,0 & 23,34 & 4,1028 \\
\hline
\end{tabular}

Keterangan: $\mathrm{SD}=$ standar deviasi

Tabel 1 menunjukkan bahwa faktor umur, berat badan maupun IMT reratanya cenderung lebih tinggi pada kelompok IRT dibandingkan kelompok peserta senam aerobik. Tingginya ketiga faktor tersebut, ternyata ada relevansinya dengan rerata kolesterol total yang ternyata lebih tinggi pada kelompok IRT (208,3 g/dl) dibandingkan kelompok senam aerobik (201,2 g/dl). Hal ini bisa membuktikan bahwa semakin bertambah umur, 
hormon estrogen semakin menurun apalagi mendekati menopause sehingga lebih berisiko terhadap tingginya kadar kolesterol total $(4,8,9)$. Semakin tinggi IMT atau berat badan seseorang, akan lebih berisiko terhadap tingginya kadar kolesterol total. Pada orang yang secara rutin melakukan olahraga, berat badannya cenderung lebih rendah dibanding yang tidak secara rutin melakukan olahraga. Hal ini disebabkan terjadinya pembakaran cadangan energi dan lemak saat melakukan olahraga (10).

Tabel 2. Distribusi frekuensi status gizi subjek

\begin{tabular}{|c|c|c|c|c|c|}
\hline \multirow{2}{*}{ Variabel } & \multicolumn{2}{|c|}{ IRT } & \multicolumn{2}{|c|}{ Peserta senam } & \multirow{2}{*}{$\mathbf{p}$} \\
\hline & $\mathbf{n}$ & $\%$ & $\mathbf{n}$ & $\%$ & \\
\hline Normal & 8 & 34,8 & 11 & 47,8 & \\
\hline Overweight & 2 & 8,7 & 6 & 26,1 & 0,33 \\
\hline Obesitas & 13 & 56,5 & 6 & 26,1 & \\
\hline
\end{tabular}

Tabel 2 menunjukkan bahwa status gizi kelompok IRT sebagian besar tergolong obesitas (56,5\%), sedangkan kelompok peserta senam aerobik hampir separuh $(47,8 \%)$ tergolong normal. Hasil uji statistik independent sample t - test menunjukkan ada perbedaan status gizi (IMT) antara kelompok IRT dan kelompok peserta senam aerobik $(p=0,33)$.

Hasil penelitian ini sesuai dengan penelitian di Amsterdam yang menunjukkan bahwa melakukan senam secara teratur dapat menurunkan berat badan, kadar kolesterol total, trigliserida, dan kolesterol LDL (3). Orang yang mengalami kegemukan atau obesitas menyimpan lemaknya di bagian perut, selebihnya di bagian paha dan pinggul. Orang gemuk cenderung memiliki kadar trigliserida tinggi yang disimpan di bawah kulit. Simpanan trigliserida ini merupakan bahan utama pembentukan very low density lipoprotein (VLDL)-kolesterol dan LDL-kolesterol di hati yang akan masuk ke dalam darah. Berkaitan dengan ini maka kegemukan atau obesitas cenderung menjadi penyebab meningkatnya kadar kolesterol total (5).

\section{Gambaran tingkat kecukupan zat gizi subjek} (karbohidrat, protein, lemak, serat, vitamin A, dan C)

Rerata asupan karbohidrat baik kelompok IRT (263,0 $\mathrm{g} / \mathrm{hr}$ ) maupun kelompok peserta senam aerobik (245,2 g/ hr) masih kurang dari angka kecukupan gizi (AKG) yang dianjurkan yaitu 310-330 g/hr. Rerata asupan protein baik kelompok IRT (100,2 g/hr) maupun kelompok peserta senam (77,9 g/hr) sudah sesuai dengan AKG yang dianjurkan yaitu $50 \mathrm{~g} / \mathrm{hr}$. Rerata asupan lemak baik kelompok IRT (116,4 g/ $\mathrm{hr}$ ) maupun kelompok peserta senam aerobik melebihi dari AKG yang dianjurkan yaitu $40-42 \mathrm{~g} / \mathrm{hr}$.

Rerata asupan serat baik kelompok IRT (12,6 g/ hr) maupun kelompok peserta senam (13,0 g/hr) masih kurang dari AKG serat yang dianjurkan yaitu $25 \mathrm{~g} / \mathrm{hr}$. Rerata asupan vitamin A kelompok IRT dan peserta senam berturut-turut 404,07 RE dan 778,14 RE dan sebagian besar sudah sesuai dengan AKG vitamin A yang dianjurkan yaitu 500 RE. Rerata asupan vitamin C kelompok IRT (41,0 mg/hr) kurang dari AKG yang dianjurkan yaitu 75 mg, sedangkan pada kelompok peserta senam aerobik $(86,7$ $\mathrm{mg} / \mathrm{hr}$ ) reratanya sudah sesuai dengan AKG.

Hasil uji Mann - Whitney menunjukkan terdapat perbedaan bermakna pada asupan protein $(p<0,05)$ antara kelompok IRT dengan kelompok peserta senam aerobik, sedangkan asupan karbohidrat dan lemak tidak berbeda secara bermakna $(p>0,05)$. Selain itu terdapat pula perbedaan secara bermakna antara kelompok IRT dengan kelompok

Tabel 3. Distribusi frekuensi konsumsi zat gizi subjek

\begin{tabular}{|c|c|c|c|c|c|}
\hline \multirow{2}{*}{ Variabel } & \multicolumn{2}{|c|}{ IRT } & \multicolumn{2}{|c|}{ Peserta senam } & \multirow{2}{*}{$\mathbf{p}$} \\
\hline & $\mathbf{n}$ & $\%$ & $\mathbf{n}$ & $\%$ & \\
\hline \multicolumn{6}{|l|}{ Karbohidrat } \\
\hline Sesuai AKG ( $\geq 450 \mathrm{~g} / \mathrm{hr})$ & 8 & 34,8 & 2 & 8,7 & 0,06 \\
\hline Kurang AKG (<450 g/hr) & 15 & 65,2 & 21 & 91,3 & \\
\hline \multicolumn{6}{|l|}{ Protein } \\
\hline Sesuai AKG ( $\geq 60 \mathrm{~g})$ & 23 & 100,0 & 19 & 82,6 & 0,01 \\
\hline Kurang AKG (<60 g) & 0 & 0 & 4 & 17,4 & \\
\hline \multicolumn{6}{|l|}{ Lemak } \\
\hline Sesuai AKG (52-56 g/hr) & 23 & 100,0 & 23 & 100,0 & 0,60 \\
\hline Kurang AKG $(<52 \mathrm{~g} / \mathrm{hr})$ & 0 & 0 & 0 & 0 & \\
\hline \multicolumn{6}{|l|}{ Serat } \\
\hline Sesuai AKG ( $\geq 25$ g/hr) & 0 & 0,0 & 1 & 4,3 & 0,98 \\
\hline Kurang AKG (<25 g/hr) & 23 & 100,0 & 22 & 95,7 & \\
\hline \multicolumn{6}{|l|}{ Vitamin A } \\
\hline Sesuai AKG ( $\geq 500$ RE) & 15 & 65,2 & 19 & 82,6 & 0,17 \\
\hline Kurang AKG (<500 RE) & 8 & 34,8 & 4 & 17,4 & \\
\hline \multicolumn{6}{|l|}{ Vitamin C } \\
\hline Sesuai AKG ( $\geq 75$ mg/hr) & 2 & 8,7 & 9 & 39,1 & 0,001 \\
\hline Kurang AKG (<75 mg/hr) & 21 & 91,3 & 14 & 60,9 & \\
\hline
\end{tabular}


peserta senam aerobik yaitu pada asupan vitamin $C(p<0,05)$, sedangkan asupan serat dan vitamin A tidak berbeda secara bermakna ( $p>0,05)$ (Tabel 3). Uji lanjutan menggunakan uji Chi - Square dilakukan untuk mengetahui apakah asupan protein dan vitamin $\mathrm{C}$ menunjukkan ada hubungannya dengan kadar kolesterol total darah. Hasil uji Chi - Square menunjukkan hanya asupan protein yang berhubungan dengan kadar kolesterol total darah $(p=0,036)$.

Berbeda dengan hasil penelitian yang dilakukan di rumah sakit Dr. Moh Hoesin Palembang menunjukkan bahwa asupan vitamin C memberikan risiko cukup bermakna yaitu 5 kali lebih besar terhadap tingginya kadar kolesterol total pada orang dengan asupan di bawah $90 \%$ AKG bila dibandingkan dengan orang yang mempunyai pola konsumsi lebih dari 90\% AKG (IK95\%: 1,25-25.73; OR $=5,67 ; p=0,03)$, demikian juga dengan asupan vitamin $B_{3}$, vitamin $\mathrm{E}$, dan serat mempunyai risiko yang relatif sama terhadap status kolesterol total (11).

\section{Pengaruh senam aerobik terhadap kolesterol total darah wanita dewasa}

Rerata kadar kolesterol total kelompok IRT (208,3 $\mathrm{g} / \mathrm{dl}$ ) hampir sama dengan rerata kelompok peserta senam aerobik (201,2 g/dl). Jika dilihat dari kategorinya maka sebagian besar kelompok IRT yang tergolong hiperkolesterolemia sebesar $52,2 \%$, sedangkan pada kelompok peserta senam aerobik sebagian besar $(56,6 \%)$ tergolong normal (Tabel 4).

Tabel 4. Status kolesterol darah subjek

\begin{tabular}{lccccc}
\hline \multirow{2}{*}{ Variabel } & \multicolumn{3}{c}{ IRT } & \multicolumn{3}{c}{ Peserta senam } & \multirow{2}{*}{$\mathbf{p}$} \\
\cline { 2 - 5 } & $\mathbf{n}$ & $\mathbf{\%}$ & $\mathbf{n}$ & $\mathbf{\%}$ & \\
\hline Hiperkolesterolemia & 12 & 52,2 & 10 & 43,5 & 0,401 \\
Normal & 11 & 47,8 & 13 & 56,5 & \\
\hline
\end{tabular}

Hasil uji statistik independent $t$ - test menunjukkan tidak ada perbedaan yang bermakna kadar kolesterol total darah kelompok IRT dibanding kelompok peserta senam aerobik $(p=0,401)$. Artinya kegiatan senam aerobik secara bermakna tidak mempengaruhi kadar kolesterol total wanita dewasa, karena perbedaan rerata kolesterol total darahnya hanya $7,1 \mathrm{~g} / \mathrm{dl}$, hasil ini tidak sesuai dengan harapan dari penelitian ini yaitu $15 \mathrm{~g} / \mathrm{dl}$ maupun jika dibandingkan dengan penelitian di Sanggar Senam "St. Anna" kota Semarang tahun 2008 (19,4 g/dl) dan penelitian di Amsterdam tahun 2000 (11,5 - 20,7 g/dl) (12,13).

Hasil penelitian ini sesuai dengan penelitian di Jepang yang menyatakan bahwa tidak ada perubahan signifikan yang diamati dalam konsentrasi serum total kolesterol dan trigliserida, namun konsentrasi serum kolesterol HDL2 meningkat secara signifikan pada 10 minggu terapi latihan. Konsentrasi serum kolesterol HDL2 meningkat secara signifikan pada 10 minggu, namun tidak ada perubahan dalam kolesterol total dan HDL3 (14).
Walaupun secara statistik perbedaannya tidak bermakna, tapi jika dilihat pada rerata kadar kolesterol total dan kejadian hiperkolesterolemia, pada kelompok IRT menunjukkan sebesar $52,2 \%$ ada kecenderungan lebih tinggi jika dibandingkan kelompok peserta senam aerobik $(43,5 \%)$. Hal ini menunjukkan bahwa jika melakukan kegiatan olahraga secara rutin dan teratur dapat bermanfaat terhadap proses regulasi kolesterol yaitu menurunkan kadar kolesterol total, LDL-kolesterol, dan trigliserida dalam darah sedangkan HDL-kolesterol meningkat secara bermakna $(5,12)$.

Penelitian di Jordan tahun 2008 juga menunjukkan bahwa senam bermanfaat terhadap penurunan kadar kolesterol, trigliserida, dan kolesterol LDL yang diakibatkan adanya penurunan berat badan disertai dengan perubahan pola makan (15). Penelitian di Alabama USA tahun 2003 juga menunjukkan aktivitas fisik secara teratur dapat mempengaruhi serum kolesterol atau profil lipid. Latihan aerobik dapat mengurangi total kolesterol dan trigliserida serta meningkatkan kolesterol HDL. Olahraga secara teratur dapat menurunkan secara signifikan kolesterol total, trigliserida, dan kolesterol LDL $(2,1+/-1,8 \mathrm{mg} / \mathrm{dL}$, $\mathrm{p}=0,001 ;-17+/-3,5 \mathrm{mg} / \mathrm{dL}, \mathrm{p}<0,0001 ;$ dan $-0,7+/-1,7$ $\mathrm{mg} / \mathrm{dL}, \mathrm{p}<0,0001)(16,17,18)$.

Fakta lain menunjukkan manfaat melakukan senam aerobik adalah mengubah komposisi tubuh. Perubahan komposisi tubuh ditunjukkan oleh perbandingan kumpulan otot, tulang, dan cairan tubuh dibandingkan dengan lemak. Latihan fisik yang bersifat aerobik dapat meningkatkan kadar kolesterol HDL dan menurunkan kadar kolesterol total, trigliserida, kolesterol LDL, dan berat badan (8).

\section{Pengaruh konsumsi makanan terhadap kadar kolesterol total darah}

Hasil uji Chi-Square menunjukkan ternyata hanya asupan protein yang berhubungan dengan kadar kolesterol total darah $(p=0,036)$. Hal ini dapat terjadi karena protein berpengaruh terhadap kadar kolesterol darah. Beberapa penelitian menunjukkan protein yang berasal dari bahan pangan hewani berpotensi menyebabkan hiperkolesterolemia, sedangkan protein yang berasal dari bahan nabati dapat mencegah terjadinya hiperkolesterolemia.

Penelitian di Laboratorium Animal Science Agricultural University Wageningen Nederlands tahun 1991 pada kelinci yang diberi makanan protein dari kedelai dengan kelinci yang diberi makanan protein dari susu, ternyata protein kedelai dapat mencegah hiperkolesterolemia. Hasil penelitian di RSCM Jakarta tahun 2003 pada manusia menunjukkan bahwa penggantian sumber protein campuran hewani dan nabati dengan protein kedelai sebagai sumber utama protein terdapat penurunan kolesterol darah sebanyak 20\%. Hal ini disebabkan protein nabati (kedelai) berpengaruh terhadap penurunan absorbsi kolesterol dalam usus halus, serta dapat 
mengurangi absorbsi kembali asam empedu. Hasil penelitian pada ayam juga menunjukkan bahwa kadar kolesterol serum kelompok kasein lebih tinggi daripada kelompok protein kedelai. Hasil penelitian pada kelinci juga menunjukkan bahwa protein hewani (biasanya kasein) lebih cholesteremic dan aterogenik daripada protein nabati (biasanya protein kedelai) $(5,19,20,21)$.

\section{KESIMPULAN DAN SARAN}

Rerata kadar kolesterol total peserta senam aerobik lebih rendah $(201,2 \mathrm{~g} / \mathrm{dl})$ dibanding kelompok ibu rumah tangga (208,3 g/dl). Kejadian hiperkolesterolemia lebih banyak pada kelompok ibu rumah tangga dibanding kelompok peserta senam aerobik. Kadar kolesterol total peserta senam aerobik dengan kelompok ibu rumah tangga tidak ada perbedaan bermakna. Hasil penelitian menunjukkan bahwa senam aerobik teratur tidak ada pengaruhnya terhadap kadar kolesterol total darah. Tingkat kecukupan protein menunjukkan ada hubungannya dengan kadar kolesterol total darah.

Asupan protein dikurangi, khususnya protein hewani karena protein hewani cenderung kandungan kolesterolnya tinggi dan dapat mempengaruhi kadar kolesterol total darah. Senam aerobik yang dilakukan secara teratur sesuai kondisi tubuh walaupun tidak ada pengaruhnya terhadap kadar kolesterol total darah, namun hasil penelitian menunjukkan adanya kecenderungan berat badan dan IMT atau status gizi yang lebih tinggi dapat meningkatkan kadar kolesterol total.

\section{RUJUKAN}

1. Bustan. Epidemiologi penyakit tidak menular. Jakarta: Rineka Cipta; 2000.

2. Semiardji G. Pengobatan dislipidemi sampai kapan?. Jakarta: PIT IImu Penyakit Dalam; 2000.

3. Aires N, Selmer R, Thelle D. The validity of self-reported leisure time physical activity, and its relationship to serum cholesterol, blood pressure and body mass index. A population based study of 332,182 men and women aged 40-42 years. Eur J Epidemiol 2003; 18(6): 479-85.

4. Baraas, F. Mencegah serangan jantung dengan menekan kolesterol. Jakarta: PT. Gramedia Pustaka Utama; 1993.

5. Waspadji S, Suyono S. Pengkajian status gizi studi epidemiologi. Jakarta: Bagian IImu Penyakit Dalam FK UI; 2003.

6. Madiyono B, Moeslichan S, Sastroasmoro S, Budiman I, Purwanto SH. Dasar-dasar metodologi penelitian klinis. Sastroasmoro S, Ismael S, editor. Jakarta: Binarupa Aksara; 1995.
7. Santoso S. Mengolah data statistik secara profesional. Jakarta: PT. Elex Media Komputindo Kelompok Gramedia; 2001.

8. Witheril D, Kereiakes DJ. Kolesterol tinggi. Susi S (Alih bahasa). Jakarta: PT. Elex Media Kompetindo Kelompok Gramedia, Anggota AKAPI; 2001.

9. Heslet L. Kolesterol. Adiwiyoto A(Alih bahasa). Jakarta: Megapon Kesaint Blanc; 2002.

10. William MH. Nutrition for health, fitness and sport. New York: Mc Graw-Hill Companies; 2007.

11. Muzakar, Dinarti K, Astuti H. Asupan vitamin B3 (niasin), C, E, dan serat terhadap disliptidemia pada penyakit jantung koroner di RS. Dr. Mohammad Hoesin Palembang. Jurnal Gizi Klinik Indonesia 2010; 6(3): 114-22.

12. Twisk JWR, Kemper HCG, Mechelen WV. Tracking of activity and fitness and the relationship with cardiovascular disease risk factors. Med Sci Sports Exerc 2000; 32(8):1455-61.

13. Sasaki J, Urata H, Tanabe Y, Kinoshita A, Tanaka H, Shindo M, Arakawa K. Mild exercise therapy increases serum high density lipoprotein2 cholesterol level in patients with essential hypertension. Am J Med Sci 1989; 297(4): 220-3.

14. Ata AB, Mansi K, Aburjai T. Lipid profile of gymnasts of the Jordan National Team (Report). American Journal of Applied Science 2008.

15. Durstine JL, Grandjean PW, Davis PG, Ferguson MA, Alderson NL, Du Bose KD. Blood lipid and lipoprotein adaption to exercise: a quantitative analysis. Sports Med 2001; 31(15): 1033-62.

16. Fan AZ, Ham SA, Muppidi SR, Mokdad AH. Validation of reported physical activity for cholesterol control using two different physical activity instruments. Vascular Health and Risk Management 2009; 5: 649-61.

17. Halverstadt A, Phares DA, Wilund KR, Goldberg AP, Hagberg JM. Endurance exercise training raises high-density lipoprotein cholesterol and lowers small low-density lipoprotein and very low-density lipoprotein independent of body fat phenotypes in older men and women. Metabolism 2007; 56: 444-50.

18. Kritchevsky D, Kolman RR, Guttmacher RM, Forbes M. Influence of dietary carbohydrate and protein on serum and liver cholesterol in germ-free chickens. Archives of Biochemistry and Biophysics 1959; 85(2): 444-51.

19. Kritchevsky D. Vegetable protein and atherosclerosis. Journal of the American Oil Chemists Society 1987; 56: 135-46.

20. Baynen AC. Dietary protein and serum cholesterol. Symposium of the 6 th Asian Congress of Nutrition (Simposium Sehari Konsep Mutakhir Peningkatan Kesehatan Jantung dan Pengaturan Gizi). Malaysia: Kualalumpur; 1991. 